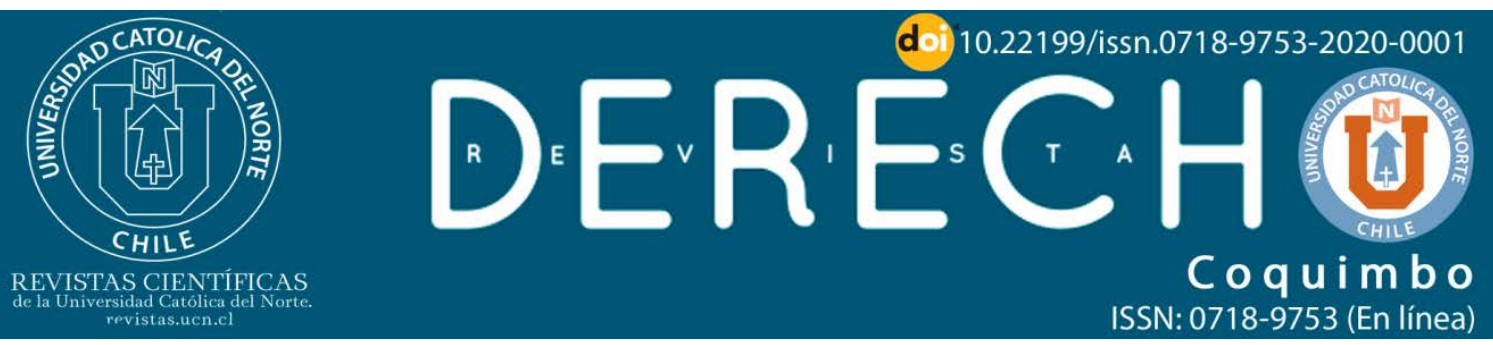

\title{
El concurso desde una perspectiva procesal
}

\section{Bankruptcy from a procedural perspective}

\begin{abstract}
Nicolás Ignacio Ariel Carrasco Delgado' (D) https://orcid.org/0000-0001-9026-3266
'Universidad de Chile, Santiago, Chile. Profesor Derecho procesal. Doctorando en Derecho, U. Autónoma de Madrid.
\end{abstract}

๑ncarrascod@gmail.com.

$(\mathrm{cc}) \mathrm{BY}$

\section{Resumen:}

El Derecho concursal posee una funcionalidad, organización y estructura que difícilmente es conciliable con una visión contractualista o privatista. La necesidad de coordinación de los acreedores (aspecto central para su buen funcionamiento) exige de instrumentos procesales que dejen de lado el puro interés de los acreedores individualmente considerados, reforzando la necesidad de su comportamiento como grupo (problema de acción colectiva). En esa lógica se explica la plena adecuación del Derecho procesal para comprender las finalidades del concurso. En ese contexto, el Derecho procesal concursal posee una serie de instrumentos que persiguen alcanzar los fines de eficiencia de los procedimientos concursales.

Palabras Clave: Derecho concursal; Derecho procesal; Análisis económico del derecho.

\begin{abstract}
:
Bankruptcy Law possesses a certain functionality, organization and structure which is not easily reconcilable with a contractualist or privatist view. The need for the coordination on the part of creditors (a central aspect of its correct functioning) demands that procedural instruments foresake the individual consideration of the interests of creditors' sole interests, and in doing so reinforces the need for them to act as a group (the collective action problem). In accordance with this logic, the complete adaptation of procedural law in order to understand its purposes is hereby explained. In this context, bankruptcy procedural law avails of a series of instruments which seek to achieve the efficiency goals of the bankruptcy proceedings.

Keywords: Bankruptcy law; Procedural law; Economic analysis of law.
\end{abstract}




\section{Introducción}

En este artículo se considera al concurso como un instituto de naturaleza procesal, ya que los instrumentos procesales (propiamente tales y conexos) permiten la coordinación de los acreedores para alcanzar la finalidad de eficiencia concursal ex post (mejora en la recuperación de los créditos) y la finalidad de eficiencia concursal de óptimo de costes (de transacción y de error). Para comenzar dos ideas preliminares. En primer lugar, la tendencia de la des-judicialización sostiene "supuestos de intervención mínima procesal" que buscan relegar a un segundo plano la participación de los órganos judiciales y estatales, por el riesgo que tiendan a perseguir objetivos diversos a los acreedores y que sean disfuncionales al régimen de mercado, "Es, precisamente, la propia consideración del derecho concursal como 'instrumento reactivo' del sistema económico de mercado lo que permite alterar el normal reparto de intereses existente en el ámbito económico" (Tirado Martí, 2009, pp. 1065-1066)-. Esa idea es contraria a quienes sostienen que el concurso es una institución administrativa - en este sentido Provinciali (1951, p. 13); D'Avack (1940, pp. 75-77).-, según la cual el concurso importa una función primaria del Estado tediente a la directa protección del interés público: suprimir de la vida económica a los entes insolventes, por el peligro que importan para el crédito y la Economía (visión "publicista" del concurso), por ejemplo "La importancia social, concluye esta posición [visión publicista del concurso] aboga por una decidida intervención del aparato público a efectos de ofrecer una base de solución que compatibilice todos dichos intereses, conforme a una planificación previamente esbozada por el propio legislador" (Goldenberg Serrano, 2013, p. 17). Sin embargo, esa calificación "publicista" del concurso, no corresponde ser asimilada a la tesis adjetiva que sostiene el fortalecimiento de los órganos jurisdiccionales.

La noción pública del concurso tendría a asignar al tribunal, como parte de su intervención procesal, una función de control y dirección que tenía por objetivo el resguardo de los intereses públicos comprometidos, de manera de velar porque los acuerdos tomados por los acreedores, de ser admisibles, no superasen los linderos que suponen las extensas limitaciones de acuerdo o contenido. (Goldenberg Serrano, 2013, p. 19)

En efecto, la tesis administrativista supone que el Estado se encuentra directamente interesado en la solución de la insolvencia (actúa como un interesado a través del ejercicio de funciones primarias de promoción de los objetivos concursales que defina). Ello se opone al ejercicio de la función secundaria propia de la jurisdicción, por la que el Estado sustituye a los particulares en la resolución de sus conflictos. El segundo aspecto preliminar refiere al vínculo que existe entre el fortalecimiento de los instrumentos procesales y la idea de regulación desde una perspectiva eco- 
nómica ${ }^{1}$ (ver; Barr, 1992; Atkinson, 1987). Se busca destacar que la tesis adjetiva no constituye un exceso de regulación indeseable en términos de bienestar. Así, Posner (1999, p. 19) ha indicado que los sistemas jurídicos competitivos (que descansan en las decisiones de los participantes, y por tanto, están basados en pocas reglas), tienden a la eficiencia de mejor manera que los sistemas que suponen menores niveles de competencia (que descansan en un fortalecimiento de la labor judicial, y por tanto, están basados en mayor cantidad de reglas), siempre que por esa vía se produzcan mayor cantidad de resultados valorables. Al respecto, podemos indicar que la tesis procesal del concurso se enmarca en un contexto en que se justifica la intervención regulatoria estatal, por medio de la dictación y vigencia de normas que reglen un procedimiento con miras a alcanzar niveles de coordinación que conduzcan, a su vez, a la obtención de los objetivos de eficiencia del Derecho procesal concursal. Ello se justifica porque no existen incentivos para que los acreedores por si solos, alcancen objetivos socialmente deseables.

\section{Conceptualización procesal del Derecho Concursal}

La tesis adjetiva posee un apoyo relevante en la doctrina nacional - dentro de los autores chilenos que sostienen la tesis procesal se encuentra Palma Rogers (1959), al señalar que el concurso es: "un procedimiento general que importa la ejecución colectiva de todos los bienes del deudor por parte de todos su acreedores, es un procedimiento doblemente universal; tanto en cuanto a los bienes que se ejecutan, como en cuanto al número de ejecutantes" (p. 29). Asimismo Núñez Ojeda y Carrasco Delgado (2014, pp.30-53) y Jara León (2009, pp. 36-38) - y extranjera, por ejemplo en el Derecho español, Garrigues Díaz-Cañabate (1987) indica que: "La nota esencial del derecho de quiebras consiste, pues, en que regula un procedimiento de ejecución colectiva o universal que descansa en el principio de comunidad de pérdidas" (p. 6), véase además Guasp Delgado (1956, p. 933), Cortés Domínguez, (2008, pp. 22-25) y Ramírez López (1959, p. 50). López Sánchez (2012) señala que: "No obstante, la contemplación del auto de declaración del concurso como un requisito formal del concurso resulta empobrecedora pues su transcendencia rebasa la simple convalidación o la mera autorización de la voluntad de acceder a la situación concursal" (pp. 32-33), a lo que agrega: "El concurso no declara cuáles son los derechos de deudor y acreedores, ni tampoco constituye al deudor o acreedores en una nueva situación jurídica. La tutela otorgada consiste en la actuación material de los derechos de los acreedores, hasta donde lo permita el valor de realización del patrimonio del deudor. Desde este punto de vista, la naturaleza de proceso de ejecución -general- resulta patente" (p. 37). Beltrán Sánchez y Sánchez Paredes (2009), dicen: "...hemos de tener en cuenta que el concurso se concibe como una solución procesal y judicial al problema de la insolvencia de modo que sólo puede hablarse

\footnotetext{
'Justificando que el Estado debería intervenir en el mercado por medio de regulaciones sectoriales cuando existan fallas de mercado.
}

Rev. derecho (Coquimbo, En línea) 2020, 27: e4040 
de concurso de acreedores si concurre un auto judicial de apertura del procedimiento" (p. 36). Tal declaración, sin embargo, debe ponderarse con el hecho que tales autores no reniegan la existencia de normas sustantivas y procesales en la legislación de insolvencia (Beltrán Sánchez y Sánchez Paredes, 2009, p. 33-34). En la base de las mencionadas opiniones se encuentra la idea del concurso concretizado en formas procedimentales determinadas. Con todo, es insuficiente analizar las definiciones legales que refieren un tratamiento de la insolvencia en términos procedimentales ${ }^{2}$. En efecto, lo que en esencia constituyen los procedimientos concursales se deriva del estado que surge de la sentencia que declara su inicio ${ }^{3}$, ya que con anterioridad no se da ninguno de los particulares efectos que dimanan del acto de su apertura. En la misma lógica, ciertas medidas previas al concurso (regulaciones pre-concurso, ver: Beltrán Sánchez, 2009), están encaminadas a alcanzar finalidades que son propias de los efectos que surgen del inicio de tales juicios, adelantando la intervención judicial a etapas en que todavía no se ha producido una insolvencia insanable ${ }^{4}$. Lo anterior, porque los procedimientos concursales, incluso cuando se den sus presupuestos sustanciales, no constituyen el único medio posible de utilización por parte del acreedor. La afirmación anterior no es una obviedad; máxime si existen posiciones privatis-

\footnotetext{
${ }^{2}$ La legislación concursal chilena estructura su regulación sobre definiciones adjetivas. Así el artículo 2 № 27 Ley 20.720, define el concepto de procedimiento concursal, señalando que corresponde a "cualquiera de los regulados en esta ley, denominados, indistintamente, Procedimiento Concursal de Reorganización de la Empresa Deudora, Procedimiento Concursal de Liquidación de la Empresa Deudora, Procedimiento Concursal de la Renegociación de la Persona Deudora y Procedimiento Concursal de Liquidación de los Bienes de la Persona Deudora". Dicha estructura procedimental resulta transversal en la Ley 20.720, así el procedimiento concursal de reorganización de la empresa deudora se encuentra contemplado en el capítulo III Ley 20.720, el procedimiento concursal de liquidación de la empresa deudora se regula en el capítulo IV Ley 20.720, y finalmente, el Procedimiento concursal de la renegociación de la persona deudora se ubica en el capítulo V Ley 20.720. En una situación similar se encuentra la legislación concursal española la que si bien no establece una definición legal de procedimiento, su estructura también es adjetiva. Así, la declaración del concurso se formula por medio de una petición judicial regulada en el artículo 7 Ley 22/2003, de 9 de julio, Concursal. A partir del cual se tramita "Del procedimiento de declaración" (capítulo II) que contiene una serie de normas adjetivas funcionales y orgánicas. ${ }^{3}$ Los procedimientos concursales generan efectos procesales que alteran el ejercicio habitual de las acciones ejecutivas individuales. En Chile la Ley 20.720 (2014), establece que la resolución de reorganización contendrá el inicio de la Protección Financiera Concursal (art. 57 inc. 1, n. 1); se suspende la tramitación de los procedimientos ejecutivos y de ejecución de cualquier clase que estuvieran en vigencia en contra del deudor (Ley $N^{\circ} 20.720,2014$, art. 57, inc. 1, n. 1b); se produce la intervención del deudor por medio de un veedor (Ley $\mathrm{N}^{\circ} 20.720,2014$, art. 57, inc. 1, n. 2a); no se podrá gravar ni enajenar los bienes del deudor, salvo los que resulten necesarios para el desenvolvimiento de su actividad (Ley $\mathrm{N}^{\circ} 20.720,2014$, art. 57, inc1, n. 2b), entre otras medidas cautelares y de protección. Efectos similares se producen con la dictación de la resolución de liquidación (Ley № 20.720, arts. 130, 134, 135, 142-144). En España, la Ley 22/2003, de 9 de julio, Concursal, establece que la declaración del concurso genera la formación de la sección segunda relativa a la administración concursal, el nombramiento y estatuto de los administradores entre otras materias (artículo 26 Ley 22/2003, de 9 de julio, Concursal). Además, el Título III de la Ley 22/2003, de 9 de julio, Concursal describe los efectos de la declaración del concurso.

${ }^{4}$ Esas reglas se concretizan en presupuestos de apertura de la insolvencia, como la insolvencia inminente en el artículo 18 del Insolvenzordnung (1994) alemán; en el artículo 2.3 Ley 22/2003, de 9 de julio, Concursal, y el artículo 2 inciso 2 Ley 20.416, que fija normas especiales para empresas de menor tamaño.
} 
tas que sostienen la existencia de un "estado concursal" previo e ineludiblemente vinculado con los procedimientos concursales (Concha Gutiérrez, 1971, pp. 10-52).

Por ello hemos definido el Derecho concursal como aquella rama jurídica que por medio de procedimientos universales y extraordinarios, persigue obtener mejoras en la recuperación de créditos, así como, la optimización de los costos involucrados, ya sea por medio de la realización de la masa activa, o bien, por la reestructuración de la misma, regido como regla general por la pars condictio creditorum. En cuanto a los elementos de tal definición podemos señalar, en primer lugar que el carácter extraordinario de los procedimientos concursales emana de su contraposición al procedimiento ordinario, de acuerdo a la clasificación del artículo 2 del Código de Procedimiento Civil ${ }^{5}$.

En segundo lugar, el carácter de universal de los procedimientos concursales refiere al hecho que ante un mismo juez se deben ventilar todos los conflictos que afectan el patrimonio del deudor. Así, la determinación del pasivo y la realización y disposición del activo busca satisfacer el interés de la totalidad de los acreedores que conforman la masa activa. Lo anterior, permite unir en un todo indivisible la situación patrimonial del fallido, con las exigencias de recuperación crediticia de los acreedores (González Granda, 2008, pp. 61-73). El carácter de universal ha sido definido como ejecución colectiva, "La quiebra es una ejecución colectiva, que tiende a la satisfacción de todos los acreedores, y de todos en igual medida, con todo el patrimonio del deudor" (Satta, 1951, p. 196).

En tercer término, los procedimientos concursales se encuentran inspirados en un principio general (según se ha reconocido en varias legislaciones, así el Código Civil) ${ }^{6}$ que corresponde a la pars condictio creditorum -principio de igualdad de los acreedores, "Los legítimos intereses comunes a todos los acreedores, en caso de cesación de pagos, consisten en que todos los créditos sean pagados en igual forma, proporción y plazo, salvo las preferencias legales, evitando que se favorezca a algún acreedor en perjuicio de la masa de ellos" (Puelma Accorsi, 1983, p. 13)-, con el que se cautela y protege por igual los créditos que concurren al reparto del producto de la realización del activo (Gómez Balmaceda y Eyzaguirre Smart, 2009, p. 25). Este principio, extiende sus efectos y se manifiesta en cada uno de los efectos que emanan de la resolución que declara el inicio de los procedimientos concursales (En la vigencia de la anterior legislación chilena, véase Gómez Balmaceda y Eyzaguirre Smart, 2009, p. 27). Lo anterior se reconoce en la actual legislación (Ley $\mathrm{N}^{\circ} 20.720,2014$, art. 288, n. 2). Ahora bien, el principio de la pars condictio tiende al resguardo de los acreedores ordinarios

\footnotetext{
${ }^{5}$ La Ley 20.720 corresponde a una norma especial diversa en los términos del artículo 2 Código de Procedimiento Civil.

${ }^{6}$ Así, el artículo 2469 Código Civil. En España la exposición de motivos de la Ley 22/2003, de 9 de julio, Concursal señala: "Se considera que el principio de igualdad de tratamiento de los acreedores ha de ser la regla general del concurso, y que sus excepciones han de ser muy contadas y justificadas" (Ley N 22/2003, 2003, art. 128, pár. 1 y 162).
} 
(aquellos que no gozan de ningún privilegio o preferencia legal) ${ }^{7}$ en el marco de la cesación de pagos de su deudor. Desde esa perspectiva, puede ser encuadrado dentro de una concepción de Derecho privado, ya que velaría por la posición relativa de ciertos acreedores. Sin embargo, desde un punto de vista sistemático, tal principio opera como una verdadera limitación legal a la libertad contractual y a la autonomía de la voluntad del deudor, de los acreedores y de ciertos terceros ${ }^{8}$; de hecho, se trata de uno de los tantos mecanismos de coordinación de la conducta de los acreedores (Peinado Gracía, 2005, pp. 440-441 y 444). Por lo mismo, el resguardo que se pretende con su consagración busca asegurar el correcto funcionamiento del mercado, y por tanto, excede al puro interés individual no siendo disponible por los particulares (Puga Vial, 1999, pp. 45-46). De hecho, supuestos de tipos penales concursales se estructuran como casos de infracción a la pars condictio ${ }^{9}$. Este principio ha sido fuertemente cuestionado por un sector de la doctrina. Al respecto se sostiene que ha devenido en irrelevante, ya que los acreedores no poseen un idéntico tratamiento para el ordenamiento concursal, las preferencias han erosionado la igualdad de trato, transformándose en la regla general (Goldenberg Serrano, 2010, pp. 74, 78-79). Además, la par condictio en el contexto de un procedimiento colectivo entendido como comunidad de pérdidas, conduciría a ciertos objetivos ("de la masa" u otros similares) que se opondrían al interés de cada acreedor (relevante para las teorías privatistas, Goldenberg Serrano, 2010, p. 76). Finalmente, también se señala que una vulneración a la igualdad de tratamiento, solo es posible de ser reconducido a una infracción de la igualdad ante la ley y no a una igualdad material entre acreedores (Goldenberg Serrano, 2010, pp. 79-80). Con todo, reconocemos en la pars condictio una utilidad de eficiencia para explicar el funcionamiento del Derecho procesal concursal, asimismo Peinado Gracía (2005, pp. 429-431 y 446-447) señala que la pars condictio es una idea fuerza de ciertas instituciones procesales, como sucede con las reglas de integración de la masa pasiva, con el ejercicio de las acciones de los acreedores ordinarios y con ciertos efectos de eficiencia ex ante (Un examen comparativo desde una perspectiva económica del principio de igualdad de trato entre los acreedores y el principio de preferencia se encuentra en: Eger, 2001). En efecto, por medio de su concreción se coadyuva a impedir la liquidación asistemática, parcial e inconexa del patrimonio del fallido, escenario que puede plantearse si es que existe una

\footnotetext{
${ }^{7}$ En el derecho chileno se encuentran regulados en el artículo 2498 Código Civil en la quinta clase de créditos.

${ }^{8}$ Por ejemplo, el artículo 463 quáter Código Penal establece tipos penales para personas diversas del deudor, lo mismo sucede con la norma del artículo 464 ter Código Penal, que en su inciso 2 sanciona al tercero en la medida que coopere o induzca a alguna de las conductas señaladas en el párrafo 7 , título IX del Libro II Código Penal. Cabe indicar que incluso el deudor se ve limitado en su autonomía contractual al ser sancionado por actos de disposición y gravamen de sus activos celebrados durante los dos años anteriores al inicio de un procedimiento concursal.

${ }^{9}$ Así, el tipo penal del artículo 463 bis Ley 20.720 (2014), sanciona penalmente la constitución de gravámenes respecto de sus bienes. Ello demuestra que la persecución de ese acto busca resguardar la igualdad de trato de los acreedores, ya que con esa garantía se rompe tal tratamiento favoreciendo a algunos acreedores. En el mismo sentido en España los artículos 259 y 259 bis Ley Orgánica 10/1995, de 23 de noviembre, del Código Penal.
} 
primacía de los remedios de ejecución individual de los acreedores, en desmedro de la imperatividad de hacerlos concurrir a un proceso unitario y universal como el concurso, en los remedios de ejecución individual concurre el principio prior tempore, potior iure, "En tal mundo (en donde no exista ley de quiebras con un principio de igualdad), cada acreedor tendría incentivos para ser el primero en obtener un fallo judicial contra el quebrado, y la carrera tenderá a privar a la compañía de sus activos con mucha rapidez para maximizar el valor de tales activos" (Posner, 1998, pp. 380-381). Asimismo, Thomas Jackson (1985, pp. 39-40) señala que la pars condictio respeta las expectativas de las partes en relación a sus probabilidades ex ante de llegar primero y de pagarse completamente (50\%) para el caso que no exista un procedimiento concursal. Así, en tal porcentaje, se minimiza el valor esperado de las posiciones de los acreedores antes de un procedimiento concursal de manera igualitaria entre todos ellos (en un sentido similar, el profesor Puga Vial (2016, pp. 48-51) señala que este principio permite la predictibilidad ex ante de un crédito al facilitar la evaluación del riesgo del deudor). Por otro lado, la pars condictio sirve de pauta hermenéutica para descifrar el sentido y alcance de los pasajes oscuros y contradictorios de los procedimientos concursales (En Chile los procedimientos concursales pueden interpretarse de acuerdo a la formulación de la par condictio; Código Civil, 2000, art. 24). En sentido contrario Goldenberg Serrano (2010, pp. 89-94).

El último elemento de la definición, corresponde al hecho que la finalidad del concurso es instar a una liquidación o una reorganización del patrimonio concursado que satisfaga de mejor manera los intereses de los acreedores (mejora en la tasa de recuperación), así como, que exista un tratamiento óptimo de los costos procesales relevantes que existen en el concurso. En esa lógica, y dados ciertos supuestos acerca de la naturaleza del comercio o industria del fallido, puede resultar más conveniente para la tasa de recuperación, optar por una reorganización, o bien, por una liquidación, y dentro de este último procedimiento, podrá ser más conveniente elegir la enajenación como unidad económica a la venta parcial de los activos del fallido. En todo caso, ambos mecanismos generan beneficios y $\operatorname{costes}^{10}$, los que deben ser valorados para adoptar la decisión más eficiente.

\section{La perspectiva procesal mejora la coordinación entre distintos acreedores y un deudor común}

Es importante destacar una premisa básica en cuanto a que el concurso no solamente enfrenta a acreedores y deudores, sino que, a acreedores con acreedores. Lo curioso es que los acreedores participan en el concurso como grupo (Beltrán Sán-

\footnotetext{
${ }^{10}$ Una unidad económica puede generar mayor valor del que es posible obtener de la venta parcializada de sus componentes. Con todo, la primera medida supone una serie de costos de transacción (acuerdos de junta de acreedores y gastos asociados) que pueden significar encarecer el mecanismo, reduciendo el retorno esperado a su ejecución.
} 
chez, 1986, p. 109; Peinado Gracía, 2005, p. 441), esto es que se encuentran inmersos en un juego de cooperación pero en donde las soluciones individuales son contradictorias con el objetivo de beneficiar al conjunto, "Bankruptc's basic procedure are designed to ameliorate a common pool problema. The key to effective implementation of this goal is to trigger bankruptcy when, and only when, it is in the interest of creditors as a group" (Jackson, 1985, p. 26) ${ }^{11}$. Parte de la dificultad es que el concurso trata a los acreedores colectivamente, en circunstancias que esos acreedores provienen desde un mundo en que tenían a su disposición mecanismos individuales de satisfacción de sus créditos, "Insolvency may be an occasion to colectivize what hitherto had been an individual remedies system" (Jackson, 1985, p. 26) ${ }^{12}$. Esa "colectivización" desde una lógica inicialmente individual, origina diferencias entre ellos (Jackson, 1985, p. 45). Más aún, esas diferencias surgen si el concurso corresponde a una alternativa predominante respecto de la ejecución individual. Tal dominancia, se demuestra en el hecho que el concurso normalmente supone la paralización o suspensión de tales ejecuciones y su sometimiento a un foro común ${ }^{13}$. Así, surge una complejidad propia del concurso que no es suficientemente analizada por las posiciones privatistas. En este sentido, tales posiciones exigen que el concurso se preocupe exclusivamente de "intereses crediticios", como si dentro de tal concepto existiera un grupo homogéneo de sujetos. Sin embargo, esa homogeneidad no existe respecto del vínculo patrimonial del acreedor con el deudor ${ }^{14}$, ni tampoco dentro de cada uno de los grupos de acreedores (en base a posiciones estratégicas). Por tanto, debemos considerar la distinta naturaleza de los acreedores, quienes a pesar de esas diferencias se ven obligados a actuar como un único grupo en razón a la colectivización concursal, "As a group, these diverse owners -bondholders, tort victims, trade creditors, shareholders, and others- would want to follow the same course as a sole owner" (Jackson, 1985. p. 31) ${ }^{15}$. Un ejemplo en el Derecho procesal concursal chileno, corresponde a la posibilidad que los acuerdos de reorganización pueden plantearse por clase o categoría de acreedores (Ley 20.720, 2014, art. 61, inc. 1). La propuesta de reorganización será igualitaria para todos los acreedores de una misma categoría (Ley 20.720, 2014, art. 61 , inc. 2), salvo que existan condiciones más favorables respecto de algunos de los acreedores de una misma clase, lo que deberá ser acordado con quórum especial por

\footnotetext{
11 “El procedimiento concursal básico es diseñado para aminorar el problema del common pool. La clave para la implementación efectiva de este beneficio es estimular el concurso, solamente cuando, esté en el interés de los acreedores como grupo [...]" N. del E.: Traducción del autor.

12 "La insolvencia será una ocasión para colectivizar lo que hasta ahora había sido un sistema de remedios individuales". N. del E.: Traducción del autor.

${ }^{13}$ El artículo 57 inciso $1 \mathrm{~N} \circ 1 . b$ Ley 20.720 (2014), establece tal efecto respecto de la resolución que declara el inicio de un procedimiento concursal de reorganización y el artículo 135 Ley 20.720 (2014), consagra ese efecto en la dictación de la resolución que da inicio al procedimiento concursal de liquidación.

${ }^{14}$ En cuanto es posible clasificar a los acreedores en múltiples sub-grupos dependiendo, por ejemplo, de su calidad de accionista, trabajador de fallido, acreedores garantizados y sin garantías, etc.

15 "Como un grupo, esos diversos dueños - poseedores de bonos, víctimas de daños, acreedores, accionistas y otros., deberían querer seguir actuando como si quien actuara fuera un mismo y único dueño" N. del E.: Traducción del autor.
} 
los acreedores desventajados. Entonces, se requiere una doble coordinación: una coordinación intra categoría ${ }^{16}$ y una coordinación entre categorías ("El acuerdo sobre la propuesta de una clase o categoría se adoptará bajo la condición suspensiva de que se acuerde la propuesta de la otra clase o categoría en la misma Junta de Acreedores..." Ley 20.720, 2014, art. 70, inc. 4). Evidentemente será difícil.

La complejidad del concurso surge desde la perspectiva de las variadas categorías de los sujetos que allí participan, lo que dificulta la existencia de coordinación. Dentro de esas categorías encontramos los acreedores parasitarios y obstructores. Se ha indicado que un acreedor parasitario es aquél que se beneficia de los acuerdos extrajudiciales alcanzados por otros acreedores y que un obstruccionista es el que impide que el acuerdo se materialice, instando por la solución judicial de la insolvencia. Ahora bien, la tesis privatista demuestra sus debilidades porque debería alentar conductas parasitarias en toda aquella cantidad que exceda al número de acreedores necesarios para alcanzar un acuerdo ${ }^{17}$, ya que ello sería consistente con el respeto de la búsqueda del interés propio (subyacente en su posición). Por su parte, es inconsistente asociar efectos negativos al acreedor obstructor si consideramos que su comportamiento lo que genera es la debida actuación legal para enfrentar una insolvencia, constituyendo una demostración de diligencia y cuidado debido más que algo susceptible de cuestionamiento (Se disiente de aquellos que cuestionan el incentivo al acreedor instante en base a catalogarlo como un obstructor. Puede verse; Pulgar Ezquerra, 2013, p. 17. Posiciones como la anterior, genera una confianza excesiva en mecanismos contractuales con el riesgo de demorar la entrada al concurso, que es lo que permite afrontar de mejor forma la insolvencia). En esa lógica, la categorización indicada demuestra las fortalezas de la tesis procesal del concurso. Comencemos con el acreedor parásito. El tratamiento de la tesis privatista realizada por el máximo exponente actual de esa posición en Chile (el profesor Juan Luis Goldenberg) no es claro sobre el punto. Señala que la externalidad positiva que se deriva de un acuerdo para aquellos acreedores que no participan de él genera "ineficiencias económicas en la lógica de la distribución de recursos". Lo anterior, debido a que esos acreedores se aprovecharían de los beneficios de un acuerdo alcanzado por otros. Recordemos que la ineficiencia se generaría en base a aquello que emana de un acuerdo entre acreedores en el contexto de un sistema de base contractual. Entonces, lo que no se explica es la razón por la que a pesar de las ineficiencias evidentes del sistema contractual, se promueve un entendimiento del concurso en ese sentido.

Para resolver este punto, la solución concursal, construida sobre la base de la colectividad, supondrá un mecanismo de coordinación tasado, construido por medio de una serie de reglas y salvaguardas para lidiar con el conflicto de

\footnotetext{
${ }^{16}$ Así, el artículo 79 inciso 2 señala las condiciones que se deben cumplir para aprobar un acuerdo de reorganización que cuente con diversas categorías de acreedores.

${ }^{17}$ De hecho, el ideal sería "acreedores funcionales" en número suficiente para alcanzar los quórum legales y "acreedores disfuncionales" en toda la cantidad restante.
} 
intereses inmanente entre los acreedores. Ellos pasarán desde la configuración de órganos deliberativos, del otorgamiento o la privación del derecho a voto, de la configuración del principio mayoritario, y, eventualmente, de la revisión judicial del contenido del acuerdo. Nada de ello se ofrece en una mecánica íntegramente contractual. (Goldenberg Serrano, 2009, p. 194)

Lo interesante es que la solución privatista no indica los mecanismos necesarios para forzar la coordinación de los acreedores. Las soluciones contractualistas fracasan en la obtención de efectos de publicidad, oponibilidad y conocimiento, requiriendo mecanismos procesales ${ }^{18}$. Así, el fortalecimiento de la lógica procesal no solamente produce una mayor coordinación entre los acreedores, sino que, adicionalmente, trata de mejor manera el problema del acreedor supuestamente parásito, no generando ineficiencia. Ello lo logra, en la generalidad de los casos, exigiendo a los acreedores cierto nivel de actividad para poder distribuir los efectos del concurso -lo que supone una fase de determinación del pasivo donde los acreedores deben concurrir a verificar sus créditos (Ley $\mathrm{N}^{\circ} 20.720,2014$, art. 170)-. Tal exigencia judicialmente reglada es valorable como instrumento, en desmedro de soluciones puramente contractuales que se ven enfrentadas a costos de transacción altísimos que impone el conocimiento de todos los potencialmente afectados por el problema de insolvencia (En este sentido a mayor número de implicados en un determinado asunto, mayores costos de transacción, Calabresi y Melamad, 1996).

Sigamos ahora con el acreedor obstructor. El cuestionamiento a la tesis privatista surge porque califica negativamente a quién insta por el concurso e impide la formación de un acuerdo. Se califica negativamente a la minoría como un grupo de sujetos que pueden afectar la voluntad común de los acreedores (Goldenberg Serrano, 2009, pp. 218-219). Nuevamente, no hay regla, pauta ni norma que sea señalada en relación a cómo debería alcanzarse la referida coordinación. Por el contrario, la tesis privatista se basa en la confianza que los acreedores visualizarán un acuerdo como más conveniente en un contexto de libertad y autonomía. Lo curioso es que la calificación del obstructor solo surge en la tesis privatista. En efecto, la posición adjetiva valora el inicio temprano de un procedimiento concursal con miras a evitar situaciones de concurso sin masa (Núñez Ojeda y Carrasco Delgado, 2011, pp. 139176), incluso, ciertas legislaciones premian al acreedor diligente que insta a su pronto inicio ${ }^{19}$. Llámese la atención que la tesis privatista genera dos inconsistencias respecto de las calificaciones anteriores. En primer lugar, el obstructor no es parasitario bajo ninguna consideración posible, ya que realiza una conducta. De lo que se sigue que resulta criticable para la tesis privatista, la diligencia del acreedor peticionario. La se-

\footnotetext{
${ }^{18}$ Sobre todo, si existen efectos que afectan a terceros ajenos a la salida concursal consensual.

${ }^{19}$ Como ocurre en España con la posibilidad que el deudor pague el crédito adeudado al acreedor instante del concurso (Ley $\mathrm{N}^{\circ} 22 / 2003,2003$, art. 19, pár. 2). Esa legislación también consagra incentivos para el concurso voluntario (aquél instado por el deudor), como por ejemplo, la conservación de las facultades de administración y disposición de sus bienes, sujetos a la autorización o conformidad de los administradores concursales (Ley N²2/2003, 2003, art. 40).
} 
gunda, es que la tesis a favor de la privatización del Derecho concursal solamente valorará como deseable un supuesto muy limitado: El acreedor que quiere negociar y que efectivamente negocia. El resto de las posibles conductas de los acreedores son objetables siendo catalogados, ya sea como parasitario o como obstruccionista.

De allí que tal posición resulta de alcance limitado, ya que más allá de lo que sabemos (que es deseable la coordinación entre los acreedores) no aporta solución al problema de diversidad de intereses que concurren en el concurso. Lo anterior se constata al describir que dentro del concepto de acreedores concurren múltiples sujetos, intereses y sub-grupos. Algunos de ellos desean el concurso, otros la ejecución individual; algunos forman parte de un grupo y deben acordar con los miembros de su categoría y además conciliar con otras categorías de acreedores; finalmente, algunos pueden tener intereses relacionados al deudor, en razón de ciertas relaciones de parentesco, amistad o algún otro acuerdo ${ }^{20}$, e instar por el ejercicio de los derechos de este último. Entonces, dice muy poco afirmar que la legislación concursal debe proteger "intereses crediticios". En tal escenario, resulta paradojal que el reconocimiento de la concurrencia de intereses diversos de los acreedores sea considerado como un sustento de las posiciones a favor de la privatización del Derecho concursal.

Sin que el sistema común contenga paliativos específicos para facilitar el acuerdo en caso que se evidencien dificultades derivadas, por ejemplo, de la multiplicidad de interesados o de la heterogeneidad de sus posiciones jurídicas y económicas. En razón de ello, la configuración de cualquier fórmula de solución de corte contractual debe enfrentar un problema muchas veces ajeno a las corrientes publicistas del derecho concursal, como es el conflicto entre acreedores. (Goldenberg Serrano, 2009, pp. 190-191)

\section{El concurso requiere de mecanismos procesales (propiamente ta- les y conexos) para generar coordinación}

Sin alejarnos del ámbito de protección "crediticio", podemos señalar que la verdadera problemática del concurso es generar posibilidades de coordinación de los acreedores. Es la visión procesal la que permite explicar debidamente tal problemática, ya que son las reglas adjetivas las más adecuadas para que ello se produzca. Por contrapartida, ello no ocurrirá si dejamos a los acreedores librados a su propia determinación en un contexto donde prevalezcan los principios de autonomía y libertad contractual (Pulgar Ezquerra, 2013, pp. 3, 5 y 19) argumenta en España a favor de una visión contractualista de los acuerdos de refinanciación, para luego sostener que en tales contratos, existe una superación del principio de relatividad contractual. Se considera difícil sostener que existe una visión contractual de los acuerdos de re-

\footnotetext{
${ }^{20}$ Tal es el caso de las personas relacionadas al deudor (Ley 20.720, 2014, art. 2, n. 26). Rev. derecho (Coquimbo, En línea) 2020, 27: e4040
} 
financiación, cuando la base misma de tal visión -el principio de relatividad- se ve atemperado. Al contrario, se ha sostenido que el Derecho procesal solo es necesario como constitución de un foro donde deban concurrir los acreedores, reduciendo el rol adjetivo de las reglas a esa función (Goldenberg Serrano, 2009, p. 118). Sin embargo, la concurrencia de los acreedores a un foro único de discusión no resulta suficiente para obtener la coordinación mencionada. La obligatoriedad o los incentivos puestos a los acreedores para participar del concurso es solo un requisito de minimis, que sigue colocando el foco en la actividad de los sujetos, relegando la función del juez a un segundo plano. Por lo mismo, se requiere de mecanismos procesales adicionales de coordinación (Jackson, 1985, pp. 20-21). Según la perspectiva adjetiva ello se consigue por medio de reglas procesales que impliquen ejercicio de jurisdicción, así como, normas procedimentales conexas a tal función. En efecto, cuando hablamos de instrumentos procesales nos referimos a la función heterónoma de resolver un conflicto, a través de una sentencia declarativa, de condena o constitutiva; así como a aspectos de funcionamiento, tratamiento y publicidad de asuntos debatidos, que requieren formas de intervención judicial con mayor o menor nivel de intensidad. Ejemplos de reglas procesales conexas corresponden a la constitución de un foro en los acuerdos de refinanciación para alcanzar ciertas mayorías, así como, los deberes de publicidad de la existencia de negociaciones en tales acuerdos. En sentido contrario, argumentando que se trataría de normas en un contexto contractualista, se pronuncia Pulgar Ezquerra (2013, pp. 17-18).

Respecto de los instrumentos procesales propiamente tales, el caso paradigmático corresponde al juez resolviendo un asunto. Un ejemplo en este sentido en materia concursal, corresponde a la labor del juez dictaminando el inicio de un procedimiento concursal cualquiera - se ha señalado que la labor de dar inicio al procedimiento concursal es propiamente jurisdiccional (Cortés Domínguez, 2008, p. 20)-. En Chile, un ejemplo de este instrumento existe en el procedimiento concursal de liquidación forzosa, donde un acreedor solicita que se dé inicio a un procedimiento de liquidación en contra de un deudor que se encontraría en alguno de los supuestos del artículo 117 Ley 20.720; ello genera la necesidad de que el juez resuelta en el marco de un procedimiento breve de conocimiento de la causal (Véase; Ley $\mathrm{N}^{\circ}$ 20.720, 2014, arts. 118, 119 y 120 n. 1, n. 2a, y n. 3). Se vuelve a activar esa función si el deudor se opone a la liquidación forzada en la audiencia inicial, originando un juicio de oposición ${ }^{21}$, que requiere de una decisión heterónoma (Véase las reglas de la Audiencia de Fallo; Ley $\mathrm{N}^{\circ} 20.2720,2014$, art. 127-129). Ahora bien, en los casos anteriores el conflicto se produce entre un acreedor y su deudor. Sin embargo, es posible identificar situaciones donde el juez ejerce una función jurisdiccional en sentido propio (Carrasco Delgado, 2016), involucrando exclusivamente a acreedores -por ejemplo, en incumplimientos de un acuerdo de reorganización (Ley $N^{\circ} 20.720,2014$, arts.

\footnotetext{
${ }^{21}$ Materia tratada en los artículos 120 n. 1 y 2d en relación a artículos 121 al 129 de la Ley 20.720 (2014).
} 
98-99), donde es posible que acreedores tengan posiciones diversas sobre la supuesta inejecución del plan-.

Por su parte, los instrumentos procesales conexos nos llevan a funciones menos evidentes de las normas adjetivas. Nos centramos en casos en que se hace necesaria la intervención del tribunal homologando un acuerdo, o bien, supuestos donde la administración de justicia facilita un foro orgánico donde puedan concurrir los interesados para alcanzar o hacer valer sus derechos, o finalmente, cuando ciertos efectos de resoluciones judiciales se aplican a determinadas decisiones con miras generar oponibilidad o publicidad. En este sentido, el Derecho concursal fija un foro donde concurren los acreedores. La solución típica del Derecho frente a la insolvencia, es que los acreedores participan en un lugar conocido y único en donde se ventilen todos los asuntos que conciernen al patrimonio del fallido ${ }^{22}$. La vis attractiva concretiza esa función conexa ${ }^{23}$. Pero también hay casos excepcionales donde los acreedores pueden alcanzar decisiones que afectan la situación patrimonial del deudor y en donde no recurren a un foro previamente establecido, sino que actúan ajenos a una estructura procedimental. Me refiero a los acuerdos extrajudiciales, los que si bien se fundan en cierto predominio crediticio de los acreedores en la solución de la insolvencia, no han podido resolver su falta de adecuación para solucionar problemas de publicidad, oponibilidad y coordinación entre los acreedores - la función de comunicación de la negociación de los acuerdos de refinanciación al deudor, por intermedio de la participación del juez del concurso en el foro de la insolvencia, demuestra las limitaciones ínsitas de la pura voluntad de los acreedores para adquirir eficacia jurídica. El efecto de suspensión mencionado no es muy distinto del efecto de protección financiera concursal regulado en Chile respecto del procedimiento concursal de reorganización (Ley $N^{\circ} 20.720,2014$, art. 57, inc. 2, n. 1), el que es concedido por medio de una resolución judicial, que sin la intervención del proceso no podría lograrse. Puede verse en Romero Seguel (2016, p. 153)-. Así, normalmente tales acuerdos requieren un nivel de actividad judicial en términos de homologación, registro o conocimiento, como ocurrió en el Derecho concursal español con los acuerdos de refinanciación, recogidos en la disposición adicional cuarta Ley 22/2003, de 9 de julio, Concursal, que no extendía sus disposiciones a terceros no partícipes del mismo (no significó una mejora en coordinación). Dadas esas deficiencias es que la Ley 38/2011, modificó el sistema de los acuerdos extrajudiciales en el sistema español. Así, para evitar la inoponibilidad de tales acuerdos y proteger la fase de nego-

\footnotetext{
${ }^{22}$ Por ejemplo, en Chile en el foro concursal debe darse en las distintas soluciones concursales que se plantean la insuficiencia patrimonial del deudor. Tanto el procedimiento concursal de liquidación (Ley $\mathrm{N}^{\circ} 20.720,2014$, art. 129, ns. 5,7 y 8), el procedimiento concursal de reorganización (Ley $\mathrm{N}^{\circ} 20.720$, 2014, art. 57, n. 5 y 6), como los acuerdos de reorganización extrajudicial (Ley № 20.720, 2014, arts. 102-114), se deben formular ante el juez concursal (de acuerdo a la Ley $N^{\circ} 20.720$, art. 3 corresponde al de domicilio del deudor), como lugar de determinación de competencia y de foro del concurso.

${ }^{23}$ Dicho efecto supone que todos los acreedores de un deudor, cualquiera sea su nacionalidad y domicilio, quedarán integrados y participarán de la masa pasiva del concurso. En España se regula en el artículo 49 Ley 22/2003, de 9 de julio, Concursal y en Chile en el artículo $128 \mathrm{~N}$ × 5 Ley 20.720.
}

Rev. derecho (Coquimbo, En línea) 2020, 27: e4040 
ciación de los mismos, se produce la suspensión de la obligación de solicitar el concurso por parte del deudor y la imposibilidad de los acreedores de pedir el concurso (Goldenberg Serrano, 2009, p. 198). Por tanto, ya no regiría el puro efecto relativo de los contratos (véase, Álvarez San José, 2005, pp. 287-299), sino que adquiere relevancia la eficacia de los remedios procesales ${ }^{24}$, sin los cuales no serían posible tales acuerdos.

El informe del veedor en el contexto de un procedimiento de reorganización simplificado es una prueba de ello (Ley No 20.720, 2014, arts. 102 al 114). A diferencia de los profesores que sustentan la visión privatista del concurso (Goldenberg Serrano, 2009, pp. 215-217), tal informe constituye un mecanismo procesal conexo para facilitar la coordinación entre los acreedores. De conformidad al artículo 57 inciso 1 No 8 Ley 20.720, tal informe plantea dos escenarios diversos a ser valorados por los acreedores. Por una parte, les indica la viabilidad de la propuesta (juicio prospectivo respecto de la probabilidad que los acreedores reciban el pago de sus acreencias en los términos y plazos indicados en el acuerdo), y por otra parte, señala el monto probable de recuperación de créditos que le correspondería a cada acreedor de acuerdo a su clase o categoría en un procedimiento de liquidación. La razón de plantear esos dos escenarios es muy sencilla. El veedor, como órgano técnico e imparcial, formula los escenarios probables de viabilidad de ambos procedimientos, siendo su labor consultiva y no resolutiva, ya que serán los acreedores quienes determinarán si el procedimiento continúa de acuerdo a la reorganización (aceptan el acuerdo), o bien, prosiguen de acuerdo a un procedimiento de liquidación (rechazan el acuerdo). Este informe técnico se hace necesario con miras a entregar mayor información a los acreedores. Se trata de un informe que reduce las asimetrías de información entre el deudor y los acreedores; aminora los costos del error (al ser formulado de manera comparativa entre el cumplimiento del acuerdo y el valor de recupero vía liquidación), y finalmente, tiende a una mayor tasa de recuperación, ya que se presume que los acreedores (manteniendo constante los otros factores) tenderán a optar por aquella alternativa que conduzca a una mejor tasa de recuperación, considerando criterios de tiempo y monto. Lo relevante es que esa optimización de recursos y mejora de eficiencia se logra con la participación de un órgano concursal, que ejerce sus funciones en un contexto procedimental, y en donde sus atribuciones están encaminadas a dotar de información relevante para el curso del proceso a quienes no pudieron obtenerla de otro modo (los acreedores). La obtención de las mencionadas finalidades se alcanza por mecanismos que suponen inversión de costos del sistema judicial que no concurren en una lógica contractual ${ }^{25}$. Sin embargo, ello no es negativo desde la eficiencia, ya que se valora la necesidad de incurrir en mayores costos si ello genera mayores tasas de coordinación (la que existirá a mayor cúmulo informacional,

\footnotetext{
${ }^{24}$ En este sentido en España la Ley 38/2011, consagró los acuerdos de refinanciación homologados. La generación de tales efectos solo emana de una actividad orgánica de homologación judicial. Dicha función rompe la lógica puramente privatista y asigna un rol fundamental al juez.

${ }^{25}$ Tal inversión atentaría contra la lógica de minimización que propugnan.
} 
en términos que los distintos acreedores conozcan su tasa de recupero y la que les corresponde a los demás partícipes). De tal forma se podrán adoptar decisiones racionales considerando las posibles estrategias de los demás. La lógica procesal no se encuentra en retirada; su función reasigna labores de eficiencia a las normas.

Por otro lado, para la tesis de la privatización del concurso, el informe carecería de importancia en cuanto la voluntad de los acreedores ya se encuentra satisfecha con la mayoría que apoya la presentación del plan de reorganización (mismo quórum exigido para su aprobación) (Ley N²0.720, 2014, art. 109).

Respecto a estos antecedentes, cabe advertir que su utilidad puede ser cuestionada en razón que ella aparece como posterior al término de la fase de negociación. De esta manera, los antecedentes reseñados [...] no se encuentran dirigidos a los acreedores que ya lo han suscrito, de manera que no pueden asociarse con fórmulas para resolver problemas de asimetría informativa en el iter negocial. Así, tampoco parecen particularmente dirigidos a los acreedores que no han formado parte del acuerdo, puesto que no pueden utilizar la información así acompañada, especialmente en lo que se refiere a la referida viabilidad y conveniencia. (Goldenberg Serrano, 2009, pp. 215216)

Por tanto, se descartaría que el informe conduzca a la coordinación de los acreedores, siendo una demostración de la "preeminencia de la solución extrajudicial". Al respecto, de ser efectiva tal apreciación, la visión privatista demostraría que la pura coordinación de los acreedores, sin apoyo de normas procesales, cumpliría con la solución del problema de aunar voluntades crediticias (el artículo 112 Ley 20.720 apoyaría una visión contractualista). Disiento de esa posición. Tal norma exige dos comentarios aclaratorios que refuerzan el rol relevante de las normas adjetivas conexas. En primer lugar, tal norma fortalece los poderes de actuación del juez, ya que de regir el principio sustantivo de base contractual no tendría lógica la intervención del órgano judicial tendente a generar una segunda instancia de ratificación de un acuerdo alcanzado fuera del juicio. La intervención judicial limita el alcance del acuerdo contractual. El segundo comentario reafirma que el juez del concurso no cumple un rol pasivo (simple ente homologador) respecto del acuerdo extrajudicial, siendo prueba de ello la facultad de citar a esta audiencia de aceptación. El legislador ha señalado que el juez citará a "todos los acreedores a quienes les afecte el Acuerdo", no limitando la citación a los acreedores que lo hayan suscrito (interpretación racional y ajustada a una visión sistemática de la Ley 20.72026) (véase; Araya Paredes y Bo-

\footnotetext{
${ }^{26}$ El artículo 113 Ley 20.720 remite la regulación de los efectos de la aprobación judicial del acuerdo extrajudicial al párrafo 4 del Título 2 del capítulo IV Ley 20.720, que regula los efectos del acuerdo de reorganización judicial. Dentro de esos efectos el principio fundamental es que tal acuerdo puede afectar a "todos los acreedores de cada clase o categoría de éste, hayan o no concurrido a la Junta que lo acuerde" (Ley N² 20.720, 2014, art. 91). Ello es aplicación del artículo 60 Ley 20.720 (2014), que señala que la propuesta de acuerdo de reorganización judicial podrá versar sobre "cualquier objeto tendiente a reestructurar los pasivos y activos de una Empresa Deudora", sin que se establezca un límite a su afectación subjetiva respecto de aquellos que lo suscriben o aceptan.
} 
fill Genzsch, 2013, p. 316-317).

En cuanto al fondo, debemos señalar que la aprobación del acuerdo de reorganización judicial requiere de una aceptación ante el tribunal por parte de los acreedores de la empresa deudora (artículo 112 Ley 20.720). Ello supone que en el tiempo intermedio entre la presentación del acuerdo y su aprobación, los acreedores pueden variar su opinión sobre el plan. Así, quienes originalmente lo apoyaban pueden terminar cambiando de parecer; como también, puede ocurrir que alguno que originalmente no adhirió (pero que es afectado por el mismo), termine aceptándolo ante el tribunal. Un factor que puede ser decisivo para tal cambio, es el informe del veedor. Esto no es extraño, ya que puede ocurrir que el informe no sea conocido por los acreedores que dieron su aprobación al acuerdo al momento de ser presentado (la ley no exige ese conocimiento ni lo presume). Así, resultan evidentes las limitaciones de comprender el fenómeno concursal desde una base puramente contractual. De aceptarse esa posición, no tendría sentido separar el acto de adherir a un acuerdo de reorganización judicial y el acto de su aceptación ante el tribunal, en aquellos casos en que la aceptación ante el tribunal sea exigida a instancia del mismo órgano jurisdiccional. Tampoco cumpliría función alguna el informe del veedor. Lo anterior, es sin perjuicio de discutir los ámbitos de facultades de ejercicio jurisdiccional que posee el tribunal concursal, debido a que la norma del artículo 112 Ley 20.720, señala en su inciso 2 que la aprobación judicial vendrá dada "previa verificación del cumplimiento de los requisitos legales". El sentido y alcance de esa frase abre la posibilidad de que incluso en el ejemplo paradigmático de vigencia de la voluntad de los acreedores (acuerdos extrajudiciales), el juez cumpla funciones jurisdiccionales en sentido propio.

En resumen, las normas procesales son las que permiten generar mayor nivel de coordinación frente a la imposibilidad que los acreedores lo alcancen. Esto no significa una confianza ciega en la regulación. Hemos indicado, que en materia procesal la regulación es deseable en supuestos de lejanía de los incentivos de los litigantes con el objetivo social perseguido en una determinada legislación (Posner, 199, p. 19). Un supuesto como el mencionado concurre en materia procesal concursal y es lo que permite justificar la regulación adjetiva, con miras a alcanzar mejoras de coordinación que posibiliten el logro de objetivos de eficiencia. Reglas bien diseñadas satisfacen esa finalidad, como un ejemplo, en el procedimiento de liquidación, la labor del órgano concursal se constituye como un agente técnico que lleva a cabo sus funciones buscando a lograr mejoras en la recuperación de créditos (Ley $\mathrm{N}^{\circ}$ $20.720,2014$, art. 40) establece una tabla de honorario único a pagar al liquidador a la fecha del reparto, la que se calculará sobre los ingresos que genere el respectivo procedimiento. Tal regulación procesal compatibiliza objetivos crediticios con los fines del órgano concursal, evitando efectos nocivos asociados al problema de principalagente, Véase Jensen, M. C. y Meckling (1976) y Pindyck.y Rubinfeld, (2001, pp. 693 y 703). 


\section{Consecuencias prácticas que se siguen de adoptar una posición procesal del concurso}

Lo que subyace al momento de determinar la naturaleza jurídica del concurso, es resolver cuál es la normativa supletoria del Derecho concursal. En efecto, la búsqueda de la naturaleza jurídica significa indagar acerca de cuáles son las propiedades esenciales de lo que se examina (Alexy, 2004, p. 163). En el Derecho, tales propiedades esenciales reconocen una fuente $u$ origen en alguna regulación más general y abstracta de aquella donde indagamos. Reconocemos una correlación de género y especie entre la denominada regulación o conjunto de Derecho común (género) y las regulaciones de sub-conjuntos normativos particulares (especie). Normalmente la diferencia entre tal género y especie vendrá dada por el proceso de codificación y descodificación, respectivamente (Barros Bourie, 1991, p. 19; González Vergara, 1998, p. 876) ${ }^{27}$. De esta forma, el Derecho concursal aparece como un sub-conjunto normativo especial. Al indagar sobre su naturaleza jurídica, generaremos un lazo o vínculo con su género (Derecho común). Pues bien, la relevancia de establecer si el Derecho concursal posee como normativa supletoria al Derecho sustancial civil o al Derecho procesal, se debe a que la finalidad de las regulaciones supletorias es entregar soluciones frente a problemas interpretativos o vacíos normativos ocasionados por la falta de completitud o coherencia en los sub-conjuntos normativos especiales, "Las normas especiales no resultan inspiradas en un principio antiético, sino en el mismo principio general que las comunes, pero con ciertas rectificaciones o modalidades que constituyen una adaptación de éste" (Alessandri Rodríguez, Somarriva Undurraga, y Vodanovic Haklicka, 1998, p. 50). En efecto, el Derecho común como pauta de interpretación clarifica el sentido y alcance del Derecho especial y como instrumento de integración sirve para resolver aquellos aspectos que no tienen una respuesta en una norma positiva, ni en los principios jurídicos específicos que rigen la normativa especial -recalcando la necesidad de establecer un sustrato teleológico para el Derecho concursal a fin de generar pautas de interpretación y jerarquías de fines, véase Goldenberg Serrano (2013 p. 33)-. Por tanto, no es baladí sostener que el Derecho concursal reconoce los objetivos del Derecho sustancial civil, o por el contrario, las finalidades del Derecho procesal. En efecto, quisiera partir mostrando las diferencias que emanan de sustentar una u otra posición dogmática. Para clarificar el punto cuestionaré los argumentos de Goldenberg Serrano como exponente de la visión privatista del Derecho concursal (En este sentido la posición de Goldenberg Serrano se acerca a la sustentada por Fabrizio Di Marzio, aun cuando se diferencia en la magnitud en que la perspectiva procesal se ve menguada. En este sentido, Di Marzio [2011, pp. 4-24]

\footnotetext{
${ }^{27}$ Si bien esa forma de entender el problema puede ser metodológicamente clara, considero que atender a consideraciones de ubicación de normas resulta de un alcance limitado. No existe razón, por ejemplo, para que el Derecho civil (caso paradigmático de Derecho común) no pueda regularse por leyes especiales, y por otro lado, que un sub-conjunto normativo especial (digamos, Derecho ambiental) no pueda en algún momento concentrar, sistematizar y armonizar su normativa por la técnica de código.
} 
sostendría una posición más extrema respecto de la pérdida de importancia del Derecho procesal en el concurso). Según tal autor, la naturaleza mercantil-sustantiva de los problemas de insolvencia nos deben conducir a dar primacía a una concepción privatista del concurso (Goldenberg Serrano, 2013, pp. 37-38). Tal concepción supone que la finalidad primordial del Derecho concursal es la de resguardar el ámbito de acción de los acreedores en cuanto a alcanzar la solución que mejor convenga a sus intereses -autonomía negocial o privada, como la mejor forma para alcanzar la satisfacción de sus créditos, "no es de extrañar que, basados en los fundamentos de la autonomía privada, se estime que son los particulares, en especial los acreedores, quienes deben determinar la solución concursal más eficiente, toda vez que se entiende que son éstos los primeros interesados en la protección de sus propios derechos" (Goldenberg Serrano, 2013, p. 30)-. En este sentido, se debe relegar a un segundo plano al Derecho procesal (intervención del Estado en un rol de dirección de los procedimientos concursales por medio de la intervención de los tribunales; Goldenberg Serrano, 2013, p. 28). Por el contrario, en lo sucesivo explicaré dos motivos por los que la perspectiva procesal explica de mejor manera el Derecho concursal (siendo su legislación común), mostrando que la perspectiva privatista se ve limitada para esos fines (En el caso español, puede verse: Pulgar Ezquerra, 2013, pp. 3-16; y Tirado Martí 2014, pp.631-645).

\subsection{El Derecho procesal permite alcanzar la finalidad del concurso de ob- tener mejoras en las tasas de recuperación de créditos}

La perspectiva privatista del concurso al poner énfasis excesivo en el acuerdo al que puedan arribar los acreedores (protegidos por el principio rector del Derecho civil de la autonomía de la voluntad - en este sentido véase López Santa María (1998, pp. 233-234) ; Díez-Picazo, y Guillón (1997, p. 373)-, no satisface debidamente la obtención de una mejora en la recuperación de activos. La perspectiva procesal ofrece una mejor explicación a la necesidad del surgimiento del Derecho concursal, en cuanto incardina sus procedimientos (de liquidación o de reorganización) con miras a alcanzar mejoras en la satisfacción de los acreedores. Este planteamiento no es paradójico, a pesar de reconocer que son los acreedores quienes conocen de mejor forma aquello que protege sus intereses (Schäfer y Ott, 2005, pp. 50-59). En efecto, la idea que los sujetos son los mejores capacitados para satisfacer sus intereses opera cuando entendemos sus elecciones de manera individual, esto es, cada uno actuando egoístamente con miras a resguardar sus preferencias (Se ha señalado que la idea del homo economicus se entiende en la lógica de cada acreedor considerado individualmente, en este sentido Picker, 1992, pp. 525-526). Esa idea es plenamente funcional en la lógica de la ejecución individual (véase, Teo; 2009, p. 118; además, Rasmussen, 1992, pp. 90-93), donde quien llega primero a embargar o subastar los activos del deudor, mejorará su posición relativa respecto del resto de los otros acreedores (principio del prior tempore, potior iure). En ese contexto, cada acreedor valorará 
independiente e individualmente sus opciones de cobro y expectativas de recuperación y adoptará la decisión más eficiente para él como único sujeto considerado. El problema es que la mencionada lógica no opera en el concurso, el que ha sido definido como un mecanismo de decisión colectiva (Baird y Jackson, 1985, p. 889), en donde concurren el deudor en insolvencia y sus acreedores. En tal mecanismo de decisión colectiva pierde sentido la primacía puramente egoísta de los acreedores (Tirado Martí, 2009, p. 1059).

Al respecto, es unánime la opinión en cuanto a que la razón de eficiencia de ese mecanismo de decisión colectiva es mejorar el valor de los activos del deudor, de forma que después del procedimiento concursal la tasa de recuperación sea mayor de aquella que existía con anterioridad (eficiencia concursal ex post) (Cabrillo y Depoorter, 2000, pp. 264). Un par de consecuencias se siguen del tal mecanismo de decisión colectiva. La primera de ellas es que la autonomía de la voluntad está sujeta a ciertas restricciones (Goldenberg Serrano, 2013, p. 31). En segundo lugar, la autonomía de los acreedores concurrirá conjuntamente con la actuación del deudor -algo que es aceptado por el mismo Goldenberg Serrano (2013, p. 37). Aceptando que la conducta del deudor limita los ámbitos de decisión y de actuación de los acreedores, véase Tirado Martí (2009, p. 1077)-, y asimismo, no es claro que todos los acreedores tengan los mismos incentivos (Picker, 1992, p. 535-537). Finalmente, quienes entregarán información relevante en el concurso no son los acreedores (sujetos predominantes en la tesis privatista), sino que, órganos concursales llamados a entregar información a los acreedores, al deudor y al juez, buscando adoptar decisiones con los menores costos de error posible ${ }^{28}$. Tales órganos concursales son fiscalizados no solamente por los acreedores (Ley $\mathrm{N}^{\circ} 20.720,2014$, art. 24, n. 1), sino que, también, por el juez (Ley $N^{\circ} 20.720,2014$, art. 18, ns. 2, 5 y 7), y en ciertas legislaciones por otros organismos públicos ${ }^{29}$. Por tanto, en presencia de escenarios de elección colectiva (como el concursal), no es evidente que los sujetos implicados puedan alcanzar el acuerdo que mayormente los beneficia. Lo anterior, aun en el caso que sea conocido cuál es ese acuerdo ideal; o incluso, se ha demostrado que no siempre existirá cooperación, a pesar de ser socialmente deseable que exista. En este sentido, posiciones estratégicas de los sujetos, problemas de información imperfecta y asimétrica, falta de confianza entre ellos, y una serie de otros factores psicológicos y contingentes, impiden que las personas alcancen el estado que más los favorece -Jon Elster (1997, p. 54) constata que en ciertos casos de juegos estratégicos puede que no exista solución alguna, en el mismo sentido, Calvo Soler (2003, pp. 92-93)-. En este sentido, la explicación a favor de la privatización del concurso resulta insuficiente porque no basta con eliminar las trabas legales, administrativas o de cualquier otra especie para

\footnotetext{
${ }^{28}$ El artículo 58 Ley 20.720 , establece una regulación por medio de la cual el veedor entrega información relevante en el concurso, para que se adopte la mejor decisión acerca de qué procedimiento concursal seguir.

${ }^{29}$ Como ocurre con la Superintendencia de Insolvencia y Reemprendimiento en sus funciones de supervigilancia y fiscalización (artículo 332 Ley 20.720).
} 
alcanzar un resultado apropiado que se derive del puro acuerdo de los acreedores. Por otro lado, se requiere que los acreedores posean información adecuada respecto de las posiciones estratégicas de los otros acreedores, siendo un importante obstáculo la imposibilidad de las partes de formarse una creencia precisa respecto de las preferencias y actitudes del otro jugador (Elster, 1997, p. 54). Ese problema se multiplica por el número de acreedores que existan en un concurso real. Por el contrario, el proceso judicial entregaba herramientas necesarias para poder generar esas creencias respecto de lo que hará la otra parte. La lógica procesal produce vías de solución imperativas de estrategias, incluso en contextos en donde no existe un juego colaborativo (como el litigio). En ese sentido, el procedimiento concursal se construye como un foro en que los acreedores deben ir entregando información acerca de sus posiciones crediticias, tales como preferencias, monto de sus créditos, fecha de generación de la deuda, existencia de garantías, y vínculos personales con el fallido (La verificación implica alegar un crédito en particular, indicar la preferencia que se posee y acompañar los títulos justificativos del crédito, ver; Ley $N^{\circ} 20.720,2014$, art. 170). Toda esa información que no existe concentrada en un contexto alternativo de ejecución individual, conduce a que las partes que concurren al concurso vayan delineando sus posibilidades de cobro no solo en consideración a lo que individualmente les resulta conveniente, sino que, también, en ponderación a su concurrencia con los otros acreedores y a las particularidades de sus créditos.

Entonces, la lógica procesal resulta más apropiada para estudiar el concurso. Una adecuada regulación de los procedimientos concursales, tenderá a favorecer un mayor fluyo de aquella información relevante para la adecuada conformación de las decisiones individuales en un contexto de elección colectiva. Incluso más, la idea del proceso como juego único ${ }^{30}$, cobra particular relevancia en el Derecho concursal, ya que las legislaciones establecen oportunidades para hacer valer los créditos (mecanismos de verificación; Ley $N^{\circ}$ 20.720, 2014, arts. 70, 71, 170 al 179), incentivando que las alegaciones de los acreedores se formulen con la mayor anticipación posible -La legislación chilena establece que los acreedores que verifiquen con posterioridad del plazo de verificación ordinaria, solo podrán ser considerados para repartos futuros y deberán aceptar lo obrado con anterioridad (Ley № 20.720, 2014, art. 179). También véase; Núñez Ojeda, Carrasco Delgado y Ortiz Rojo (2012, pp. 279-280)-. Además, adquiere sentido la lógica procesal de producción de información a favor del resto de los acreedores en relación a las alternativas completas y definitivas que sostienen los distintos participantes, existiendo mayor probabilidad de alcanzar resultados colaborativos si las partes puedan conocer las posiciones de los otros participantes como si fueran posiciones a firme y no susceptibles a cambios (La Guía Legislativa sobre el Régimen de la Insolvencia, elaborada por la Comisión de las Naciones Unidas para el Derecho Mercantil Internacional, 2006, señala que las solicitudes que los acreedores

\footnotetext{
${ }^{30}$ Un juego procesal es el que concluye con efecto de efecto de cosa juzgada sustancial, lo que impide que el mismo asunto pueda volver a plantearse.
} 
efectúen respecto de sus créditos son relevantes para determinar qué acreedores tendrían derecho a voto y de qué manera lo podrán ejercer). Por el contrario, la idea de autonomía de la voluntad de los acreedores se ve relegada fatalmente por su incapacidad para mejorar los niveles de información que los acreedores requieren a fin de alcanzar resultados colaborativos que sean pertinentes en el proceso. De hecho, exacerbar la lógica de la libertad negocial de los acreedores puede conducir a resultados contraproducentes con la operatividad de la elección colectiva referida, asignando un valor demasiado alto a la posición de cada acreedor, tendiendo a que las decisiones colectivas que se adopten en los procedimientos concursales busquen la unanimidad $^{31}$. Esta última solución no se aviene con la regla de decisión que regularmente rige en los concursos, estimándose más cercana a la eficiencia las reglas de mayoría (Se ha señalado que una propuesta de eficiencia es reducir los niveles de quórum de aprobación de mecanismos de coordinación en los convenios, sobre el entendido que la coordinación de los acreedores resulta compleja; Bonilla, Fischer, Lüders, Mery, \& Tagle, 2004). Además, la lógica privatista afecta la obtención de la eficiencia concursal ex post, debido a que el concurso persigue un fin que excede el puro interés individual de cada acreedor. De hecho la lógica de la obtención de una mejora en la tasa de recuperación de créditos, no está pensada para la mayor tasa de recuperación de créditos para el acreedor $A, B, C \circ D$, individualmente considerados; sino que, está pensada como una mejora en la tasa de recuperación de crédito para el conjunto de todos los acreedores, en este sentido, se pronuncia Tirado Martí (2009, pp. 1084) al referir a la función solutoria del concurso. En el mismo sentido, indica la necesidad de que el órgano concursal lleve a cabo su función tendiendo a la maximización del bienestar de todos los acreedores en la mayor medida posible, Tirado Martí (2009, pp. 1088-1089). Así por ejemplo, las propuestas de regulación de mecanismos de reorganización tienden a mejorar a la situación general de los acreedores, véase Hart, La Porta Drago, López de Silanes y Moore (1997) y Cabrillo y Depoorter (2000, pp. 270-272). Ello significa que si en el estado anterior al concurso la tasa de recuperación era del $20 \%$, la idea es que luego del concurso esa tasa sea, por lo menos, del 21\%, con prescindencia si con ello mejoramos a 3 de 10 acreedores, o solo a 1 - Goldenberg ha reconocido que la finalidad del concurso era la mejora de la eficiencia concursal ex post respecto de todos los acreedores: "La idea de los incentivos indirectos se vinculan necesariamente con una de las finalidades últimas (al menos desde la perspectiva económica) del concurso, como es dejar a los acreedores (en conjunto) en una mejor posición que aquélla que les correspondería de sujetarse a la lógica de la ejecución individual" (Goldenberg Serrano, 2012, p. 327) -. La lógica de puro egoísmo individual de cada acreedor es insuficiente para dar una respuesta satisfactoria al problema de decisión colectiva del concurso. Si no aceptamos que el concurso busca favorecer un interés de los acreedores en su conjunto, por ejemplo Warren (1997, pp.

\footnotetext{
${ }^{31}$ En Chile existen reglas de mayoría, tales como normas de quórum simple (Ley $\mathrm{N}^{\circ} 20.720,2014$, art. 2 , n. 34); quórum calificado (Ley $\mathrm{N}^{\circ} 20.720,2014$, art. 2, n. 33), y quórum especial (Ley $\mathrm{N}^{\circ} 20.720,2014$, art. 2, n. 32).
} 
1389-1392) ha argumentado que la opción por satisfacer a los acreedores en su conjunto se impone por sobre la protección del principio de prioridad absoluta de los acreedores. Esto último significa que la finalidad de eficiencia asociada a todos los acreedores prevalece frente a la mera protección de las titularidades y ordenes de prelación de créditos previos al concurso, (sin que ex ante podamos saber qué acreedores serán beneficiados), entonces, no tiene sentido que demos inicio a un procedimiento más caro, lento y complejo que su alternativa de la ejecución individual. De hecho, el tránsito desde la liquidación inorgánica del patrimonio del deudor (por medio de múltiples juicios individuales) al concurso, tiene por objeto garantizar que en un único foro podamos adoptar una decisión que logre revalorizar el activo del deudor, y así, incrementar la tasa de recuperación. Para lograrlo existen órganos concursales que tienden a mejorar la administración del deudor ${ }^{32}$, así como a formular formas de venta que mejoren su valor de acuerdo a la naturaleza de los bienes respectivos $^{33}$.

Desde esta mirada, el proceso no se ve relegado (Goldenberg Serrano, 2013, pp. 16 y 27), ya que la preocupación se traspasa al examen de las reglas adjetivas que permitan generar la coordinación necesaria, incluso a costa de la autonomía de los acreedores, a fin que se produzca el resultado de eficiencia concursal ex post. Lo anterior, no significa sostener una visión estatista del mercado como normalmente se asocia la predominancia del Derecho procesal en el concurso (Provinciali, 1969, p. 13); tampoco implica manifestar que los órganos concursales deben resguardar intereses extra-crediticios, ni menos, que deban alterarse las preferencias legales con miras a forzar una coordinación -en este sentido, Cabrillo y Depoorter (2000, pp. 277278) y Flint Blanck (2008, p. 38)-. Por el contrario, la visión procesal se basa en la búsqueda de consideraciones de eficiencia, en cuanto a la generación de reglas concursales que satisfagan un óptimo procesal ${ }^{34}$, así como, la eficiencia concursal ex post, como preocupación del legislador o del juez. En tal búsqueda, la explicación privatista basada en la autonomía que sustenta el acuerdo de los acreedores me parece limitada, para constituirse como marco de referencia de Derecho común respecto del concurso.

\footnotetext{
${ }^{32}$ Por ello los órganos concursales de administración son entidades profesionales y técnicas, existiendo requisitos en ese sentido. En la legislación concursal chilena, los veedores deben cumplir una serie de requisitos vinculados con su cualificación profesional (Ley 20.720, 2014, art. 13), lo que incluye pruebas de conocimiento (Ley 20.720, 2014, art. 14).

${ }^{33}$ Normalmente las legislaciones contemplan mecanismos de realización de acuerdo a la naturaleza especial de los bienes (muebles, valores mobiliarios, inmuebles, etc). Es importante que la legislación contemple situaciones de flexibilidad para determinar la más adecuada manera de venta. En el Derecho concursal chileno, ver, Ley 20.720, 2014, ars. 207 al 216.

${ }^{34}$ Entendemos por óptimo de eficiencia de Derecho procesal el punto donde se igualan los costos marginales del sistema judicial con los beneficios marginales del sistema judicial.
} 


\subsection{El Derecho procesal corresponde a la norma supletoria del Derecho concursal porque efectúa un adecuado tratamiento de los costos de transacción que intervienen en el concurso}

Ahora debemos centrarnos en el examen de los costos que intervienen en el concurso y la importancia de entender que el Derecho concursal se traduce en relaciones de acreedores-deudor, más que relaciones acreedores-acreedores. Al respecto, la visión privatista trata de regular conflictos entre acreedores, ya que serían ellos: "Quienes deben determinar la solución concursal más eficiente, toda vez que se entiende que son éstos los primeros interesados en la protección de sus propios derechos" (Goldenberg Serrano, 2013, p. 30). Debido a lo anterior, la privatización del Derecho concursal supone entregar a los acreedores las herramientas apropiadas para alcanzar el acuerdo que permita "la protección de sus propios derechos". Allí es donde el Derecho sustancial entra en escena, ya que una herramienta adecuada para tal finalidad lo constituye el principio de autonomía privada y negocial (catalogado como punto focal de la legislación concursal; Goldenberg Serrano, 2013, p. 11). Así, cualquier limitación, traba o entorpecimiento implica afectar los espacios de decisión de los acreedores. Por tanto, se debe excluir del problema concursal la preocupación por intereses extracrediticios (Goldenberg Serrano, 2013, pp. 22, 25-26, 35-36); el principio de la pars condicio creditorum debe ceder en tanto no daría una respuesta adecuada a la participación de los acreedores en el concurso;

f. La proporcionalidad, en suma, constituye una respuesta legislativa al problema de la concurrencia de créditos, amparada en los beneficios económicos que resultan de su establecimiento: la expansión del riesgo de insolvencia en el mayor número de acreedores posibles y la reducción de costos de transacción y supervisión de la conducta del deudor y de los demás acreedores. (Goldenberg Serrano, 2010, p. 95)

Y por cierto, deben reducirse los costos de transacción que afecten la posibilidad de alcanzar el acuerdo entre los acreedores - "Consecuencia inequívoca de ello será el aumento de poder decisorio de los particulares y la eliminación de trabas (inútiles) que impidan o limiten la efectividad de sus acuerdos" (Goldenberg Serrano, 2013, p. 30)-.

Pues bien, en la necesidad de reducir tales costos de transacción es donde se manifiesta la diferencia entre una posición privatista y procesal del Derecho concursal. Al respecto, para la visión a favor de la privatización del concurso, la existencia de trabas o costos de transacción se traduce en restricciones para satisfacer el realce de la autonomía de los acreedores. Desde esa perspectiva, la eliminación de los costos de transacción aparece como sensata y razonable, ya que en la medida que concurran tales costos aumentan las dificultades para alcanzar el acuerdo que los acreedores consideren apto, y con ello, reducen sus posibilidades de recuperación de créditos (el pago de tales costos disminuye el valor esperado del concurso). Así, la preocupación fundamental de la visión privatista del Derecho concursal es alcanzar una 
eficiencia en términos de Coase (minimizar los costos que impiden el ejercicio de la autonomía privada). En este sentido, Coleman (1980, p. 542) señala que cuando las condiciones del primer elemento del teorema de Coase son satisfechas, la eficiencia se asegura por medio de mercados libres sin coacción, esto es, sin intervención del Estado (por ejemplo, por medio de sus tribunales). El teorema de Coase pretende, por tanto, resguardar la lógica de intercambio, entendiendo que ella se ve facilitada cuando removemos los costos de transacción. El principio de autonomía privada impone ese amplio ámbito de acción, con los menores costos de transacción posibles, y resguardando ciertos límites de mínimo (orden público o el interés de terceros; Código Civil, 2000, arts. 1462 y 1545). Sin embargo, la explicación privatista no es convincente y menos apropiada para la lógica en que el legislador ha configurado el concurso. Al respecto, Goldenberg Serrano (2013) acepta que el concurso surge cuando se ha "construido el concurso" y "delimitado el foro" (p. 31). Se requiere, entonces, indagar cuáles son los costos de transacción que encontramos en tal "foro". Al respecto, dado que el "foro" en cuestión se concretiza en procedimientos concursales, entonces, los "costos de transacción", corresponden a los denominados "costos del sistema judicial" (Calabresi, 1984, p. 349) (especie del género "costos de transacción"). De la respuesta a esa pregunta tendremos la solución acerca de si la minimización es el tratamiento adecuado de los costos de transacción que allí intervienen.

Con todo, el tratamiento de minimización no resulta pertinente para el foro concursal. Ello por las siguientes tres razones. En primer lugar, el tratamiento adecuado de los costos relevantes que participan en el concurso es un tratamiento de óptimo y no de minimización. En este sentido, a diferencia de Posner (1998, p. 549551), Cooter y Ulen (1998, pp. 476-477), Pastor Prieto (1993, p. 50) y Shavell (2004, p. 451 ), sostengo un tratamiento de óptimo ${ }^{35}$, porque los costos relevantes que intervienen en el procesos (costos del sistema judicial y costos de error de la decisión judicial) están inversamente relacionados. En segundo lugar, la posición privatista omite cualquier referencia al error concursal como un costo que debiera ser minimizado. Ello se debe a la asunción que toda decisión que emane de un acuerdo de acreedores es correcta, racional y debe ser ejecutada. Sin embargo, no podemos derivar una despreocupación absoluta por el error concursal, ya que por mucho que se desee aumentar la relevancia de la autonomía negocial de los acreedores, no se puede obviar lo evidente, en cuanto a que la regulación concursal contiene una preocupación por el error. Precisamente el hecho que el foro concursal sea un contexto de decisión judicial colectiva, implica la intervención de muchos sujetos que sostienen posiciones encontradas. Allí se adoptan decisiones que pueden ser correctas o equivocadas de acuerdo a parámetros internos de justificación; pero si queremos reducir los costos del error, aumentaremos los costos de transacción (costos del sistema judicial). Como consecuencia de ello, la "eliminación de trabas que impidan o limiten la efectivi-

\footnotetext{
${ }^{35}$ Entendemos por óptimo de eficiencia de Derecho procesal el punto donde se igualan los costos marginales del sistema judicial con los beneficios marginales del sistema judicial.
} 
dad de sus acuerdos", no se puede alcanzar pura y simplemente. Se requiere aceptar que la preocupación por el error es razonable, incluso, cuando imponga un costo a tales acuerdos. Adicionalmente, la visión privatista no atiende al hecho que nos encontramos en un contexto que no es el ideal de Coase -primer presupuesto de su teorema- (En una situación sin costes de transacción, se podría lograr un resultado eficiente con independencia de la norma o decisión judicial atributiva del derecho elegida, véase; Tavano de Aredes, 2006), sino que, es su segunda mejor opción segundo presupuesto de su teorema- (La solución eficiente no puede lograrse con independencia de la norma jurídica o decisión judicial elegida, siendo preferible aquella norma o decisión que reduzca al mínimo los efectos de los costes de transacción; Tavano de Aredes, 2006, pp. 60-61). En esa opción existen costos de transacción relevantes e intervienen jueces o legisladores con miras a alcanzar una situación de eficiencia de segundo orden ${ }^{36}$. En este sentido, si queremos sencillamente homologar un acuerdo privado de los acreedores como aspecto sagrado del concurso, entonces, podemos cuestionarnos por la existencia misma de los procedimientos concursales (Hart, 2000, pp. 1-3). En tercer lugar, la posición privatista parte del supuesto que lo relevante en el concurso es promover la autonomía de los acreedores, en el sentido que el conflicto que supone el concurso es un conflicto entre acreedores (Goldenberg Serrano, 2013, p. 30). Con todo, en el concurso también interviene el deudor; siendo las relaciones jurídicas concursales fundamentalmente acreedoresdeudor -se ha señalado que si no existiera un foro de múltiples partes como ocurre en el concurso, los acreedores preferentes presionarían al deudor para proceder a la venta de los bienes en garantía en caso de incumplimiento. Tal idea refleja que la existencia del concurso impide que los acreedores sometan al deudor como sujeto relevante, dándole a éste la posibilidad de optar por una salida distinta (la reorganización), como consecuencia, en el contexto del concurso, el deudor pasa a ser un sujeto a considerar en el examen de las estrategias de las partes, véase Miller y Waisman (2005, p. 172-174)-. Así, la perspectiva que sostiene la relevancia focal de la autonomía de una de las clases de sujetos participantes del concurso (los acreedores) omite a otro sujeto relevante (el deudor). El problema es que el deudor no posee ningún interés en maximizar un acuerdo de sujetos que poseen posiciones contrarios a sus intereses. Al respecto tres consideraciones. Primeramente, uno de los ejemplos clásicos en que el acuerdo de los acreedores se manifiesta (los convenios, acuerdos de reorganización, etc.), no son indiferentes respecto del rol de participación del deudor. Así, las legislaciones siempre han establecido algún nivel de intervención del fallido en tales instrumentos ${ }^{37}$. En segundo lugar, parece razonable entender que la pura libertad de los acreedores para alcanzar una solución a la insolvencia carece de

\footnotetext{
${ }^{36}$ La situación de eficiencia de primer orden o ideal, sería aquella que se obtiene en una situación en donde no existen costos de transacción (primer principio del teorema de Coase).

${ }^{37}$ Por ejemplo, en Chile se requiere el consentimiento del deudor para alcanzar un acuerdo de reorganización extrajudicial (Ley $\mathrm{N}^{\circ} 20.720,2014$, arts. 102 y ss.) como para alcanzar un acuerdo de reorganización judicial (Ley № 20.720, 2014, art. 54).
} 
sustento cuando debe compatibilizarse con posiciones estratégicas judiciales del deudor. Al respecto, el deudor puede aprovechar un sesgo normativo que fuerce el concurso hacia soluciones distintas de las que pueden desear los acreedores ${ }^{38}$, o bien, el deudor puede utilizar su mayor información acerca de su situación patrimonial para alterar el equilibrio que podría alcanzarse entre los acreedores. Tal posición estratégica, que en ningún caso desaparece en el concurso, es disruptiva de la idea predominante de la libertad o autonomía privada que sostiene la perspectiva privatista. Finalmente, omitir la participación del deudor omite los costos que esa intervención puede generar en el proceso - el nivel de gasto o inversión en juicio de una parte depende del nivel de gasto o inversión en juicio de la otra (Cooter y Rubinfeld, 1989, pp. 1087-1089)- (los que no son irrelevantes) ${ }^{39}$.

\section{Conclusiones}

Podemos concluir que el Derecho concursal posee una naturaleza procesal o adjetiva, porque el recurrir a ésta última área jurídica se explica de mejor manera la necesidad de generar coordinación entre los sujetos implicados en el concurso, con miras a alcanzar objetivos de eficiencia de mejoras en la tasa de recuperación de activos y de óptimos de eficiencia. El Derecho procesal provee instrumentos de coordinación plenamente adecuados a la lógica del concurso en desmedro de la posición privatista que posee evidente limitaciones para explicar la coordinación necesaria entre los acreedores.

Once one sets aside the question of the need of individuals for a financial fresh start, the remaining principal role of bankruptcy law has been and should be more procedural than sustantive. That goal is to permit the owner of assets to use those assets in a way that is most productive to them as a group in the face of incentives by individual owners to maximize their own positions... (Jackson, 1985, pp. 6-7) ${ }^{40}$.

\footnotetext{
${ }^{38}$ Ello puede ocurrir en Chile donde la Ley 20.720 (2014, arts. 85, 88, 97-98), establece un sesgo a favor de la reorganización, al darle una segunda chance a la reorganización a pesar de existir incumplimientos de un acuerdo de reorganización previo.

${ }^{39}$ Una posición de negociación del deudor, puede llevar a salidas negociadas al concurso, o bien, a aportar información adecuada respecto de la gestión de su negocio o de la existencia de activos y la posibilidad de sacarles provecho. Por el contrario, una posición confrontacional del deudor, puede conducir a mayores costos judiciales por parte de los acreedores, fiscalizando la labor de los órganos concursales de administración o evitando conductas oportunistas del deudor.

40 "Una vez que surge la cuestión acerca de la necesidad de los individuos para un nuevo comienzo, el principal rol que se mantiene en el concurso ha sido y debería ser más procesal que sustantivo. Este objetivo permite a los dueños de los activos usar aquellos activos en la forma que sea más productiva para ellos como grupo, enfrentando los incentivos de los individuos dueños para maximizar su posición" N. del E.: Traducción del autor.
} 


\section{Referencias Bibliográficas}

Alessandri Rodríguez, A., Somarriva Undurraga, M. y Vodanovic Haklicka., A. (1998). Tratado de derecho civil: partes preliminar y general (6a ed.). Santiago: Editorial jurídica de Chile.

Alexy, R. (2004). The nature of legal philosophy. Ratio juris, 17(2), 156-167. doi: 10.1111/j.1467-9337.2004.00261.x

Álvarez San José, M. (2005). El poder de decisión de los acreedores en el concurso. Madrid: Thomson Civitas.

Araya Paredes, I. y Bofill Genzsch, O. (2013). Análisis y comentarios a la reforma al Régimen Concursal (Boletín № 8324-03). Revista de derecho (Santiago. En Línea), (4), 281-323. Recuperado de https://bit.ly/38yiKhu

Atkinson, A. B. (1987). Introductory comments. European economic review, 31(1-2), 177-181. doi: 10.1016/0014-2921(87)90029-8

Baird, D. G. y Jackson, T. H. (1985). Cases, problems, and materials on bankruptcy. Boston, MA: Little, Brown.

Barr, N. (1992). Economic theory and the welfare state: a survey and interpretation. Journal of economic literature, 30(2), 741-803. Recuperado de https://bit.ly/3aGqVtA

Barros Bourie, E. (1991). Tensiones de derecho actual. Revista de derecho y jurisprudencia y gaceta de los tribunales, 88(1), 119-143.

Beltrán Sánchez, E. (1986). Las deudas de la masa. Bolonia: Publicaciones del Real colegio de España.

Beltrán Sánchez, E. (2009). La defectuosa concepción del presupuesto objetivo. En E. Beltrán Sánchez y P. Prendes Carril (Dir.), Los Problemas de la ley concursal (pp. 69-78). Cizur Menor: Civitas Thomson Reuters.

Beltrán Sánchez, E. y Sánchez Paredes, M. L. (2009). Cinco años de aplicación de la Ley Concursal. Cizur Menor: Civitas Thomson Reuters.

Bonilla, C., Fischer, R., Lüders, R., Mery, R. y Tagle, J. (2004). Análisis y recomendaciones para una reforma de la Ley de quiebras. Centro de Economía Aplicada de la Universidad de Chile. Recuperado de https://bit.ly/2IBekfa

Cabrillo, F. y Depoorter, B. (2000). Encyclopedia of law and economics. En B. Boudewijn y G. De Geest (Eds.), Encyclopedia of law and economics (Vol. 5, pp. 261289). Cheltenham: Edward Elgar. 
El concurso desde una perspectiva procesal.

Calabresi, G. (1984). El coste de los accidentes: análisis económico y jurídico de la responsabilidad civil. (J. Bisbal, Trad.). Barcelona: Ariel.

Calabresi, G. y Melamed, A. D. (1996). Reglas de propiedad, reglas de responsabilidad y de inalienabilidad: una vista de la catedral. Estudios públicos, (63), 347-391. Recuperado de https://bit.ly/336Nu7X

Calvo Soler, R. (2003). Uso de normas jurídicas y toma de decisiones. Barcelona: Gedisa.

Carrasco Delgado, N. (2016). El rol de los controles procesales en los acuerdos de reorganización simplificados o extrajudiciales en el Derecho procesal concursal chileno. En D. García Bartolomé, S. Pacchi y G. Pérez del Blanco (Coords.), Estudios sobre derecho de la insolvencia (pp. 597-618). León: Eolas.

Código Civil. Diario Oficial de la República de Chile, Santiago, Chile, 30 de mayo de 2000. Recuperado de http://bcn.cl/1uqm8

Código Penal. Diario Oficial de la República de Chile, Santiago, Chile, 12 de noviembre de 1874. Recuperado de http://bcn.cl/1 uvs0

Coleman, J. L. (1980). Efficiency, utility, and wealth maximization. Hofstra law review, 8, 509-551. Recuperado de https://bit.ly/2TXayBW

Comisión de las Naciones Unidas para el Derecho Mercantil Internacional. (2006). Guía legislativa sobre el régimen de la insolvencia. Recuperado de http://bit.ly/3d8Q07a

Concha Gutiérrez, C. (1971). El proceso de quiebras. Valparaíso: Editorial López Vivanco.

Cooter, R. D. y Rubinfeld, D. L. (1989). Economic analysis of legal disputes and their resolution. Journal of economic literature, 27(3), 1067-1097. Recuperado de https://bit.ly/38HiQmO

Cooter, R. y Ulen, T. (1998). Derecho y economía. (Suárez Eduardo L., Trad.). México, DF: Fondo de Cultura Económica.

Cortés Domínguez, V. (2008). La naturaleza jurídica de la declaración judicial de concurso. En M. Olivencia, C. Fernández-Nóvoa y R. Jiménez de Parga (Dirs.), Tratado de derecho mercantil (Vol. 47, pp. 17-39). Madrid: Marcial Pons.

D’Avack, C. (1940). La natura giuridica del fallimento. Padova: CEDAM.

Díez-Picazo, L. y Gullón, A. (1997). Sistema de derecho civil (9a ed., Vol. 1). Madrid: Tecnos.

Di Marzio, F. (2011). Il diritto negoziale della crisi dimpresa. Milano: Giuffrè. 
Eger, T. (2001). Bankruptcy regulations and the new german insolvency law from an economic point of view. European journal of law and economics, 11(1), 29-46. doi: 10.1023/a:1008761612177

Elster, J. (1997). Egonomics. (I. Cudich, Trad.). Barcelona: Gedisa.

Flint Blanck, P. (2009). Eficiencia y racionalidad en el sistema concursal: el caso peruano. Advocatus, (21), 301-340. Recuperado de http://bit.ly/2TJcYWa

Garrigues Díaz-Cañabate, J. (1987). Curso de derecho mercantil (7a ed., Vol. 5). Bogotá: Temis.

Goldenberg Serrano, J. L. (2009) Los acuerdos extrajudiciales en la legislación concursal. Revista de derecho de la empresa, (20), 73-100.

Goldenberg Serrano, J. L. (2010). Consideraciones críticas respecto al denominado principio de la par condicio creditorum. Revista chilena de derecho, 37(1), 73-98. doi: $10.4067 /$ s0718-34372010000100004

Goldenberg Serrano, J. L. (2012). El problema temporal en el inicio de los procedimientos concursales. Ius et praxis, 18(1), 315-346. doi: 10.4067/s071800122012000100010

Goldenberg Serrano, J. L. (2013). Bases para la privatización del derecho concursal. Revista chilena de derecho privado, (20), 9-49. doi: 10.4067/s071880722013000100001

Gómez Balmaceda, R. y Eyzaguirre Smart, G. (2009). El derecho de quiebras. Santiago: Editorial jurídica de Chile.

González Granda, P. (2008). Jurisdicción y competencia en materia concursal. En M. Olivencia, C. Fernández-Nóvoa y R. Jiménez de Parga (Dirs.), Tratado de derecho mercantil (Vol. 47, pp. 41-126). Madrid: Marcial Pons.

González Vergara, P. (1998). Codificación y técnica legislativa. Revista chilena de derecho, 25(4), pp. 867-895. Recuperado de http://bit.ly/337WZE6

Guasp Delgado, J. (1956). Derecho procesal civil. Madrid: Instituto de Estudios Político.

Hart, O., La Porta Drago, R., López de Silanes, F. y Moore, J. (1997). A new bankruptcy procedure that uses multiple auctions. European economic review, 41(3-5), 461-473. doi: 10.1016/s0014-2921(97)00015-9

Hart, O. (2000). Different approaches to bankruptcy. NBER working paper, (7921), 118. doi: $10.3386 / w 7921$ 
El concurso desde una perspectiva procesal.

Insolvenzordnung. BGBI. I S. 2866, 5. Oktober 1994. Recuperado de http://bit.ly/2vka1St

Jackson, T. H. (1985). The Logic and limits of bankruptcy law. Discussion paper program in law and economics Harvard law school. Recuperado de http://bit.ly/2ICrkB8

Jara León, O. (2009). La sentencia de quiebra. Chile: Editorial Jurídica.

Jensen, M. C. y Meckling, W. H. (1976). Theory of the firm: managerial behavior, agency costs and ownership structure. Journal of financial economics, 3(4), 305-360. doi: 10.1016/0304-405x(76)90026-x

Ley $N^{\circ}$ 1.552. Código de procedimiento civil. Diario Oficial de la República de Chile, Santiago, Chile, 30 de agosto de 1902. Recuperado de http://bcn.cl/1uw3q

Ley N²0.416. Diario Oficial de la República de Chile, Santiago, Chile, 03 de febrero de 2010. Recuperado de http://bcn.cl/1 uz9c

Ley N²0.720. Diario Oficial de la República de Chile, Santiago, Chile, 09 de enero de 2014. Recuperado de http://bcn.cl/1 uvtk

Ley N 10/1995. Boletín Oficial del Estado, Madrid, España, 24 de noviembre de 1995. Recuperado de http://bit.ly/33mOhSI

Ley N²2/2003. Boletín Oficial del Estado, Madrid, España, 10 de julio de 2003. Recuperado de http://bit.ly/3cTIOXz

Ley $N^{\circ}$ 38/2011. Boletín Oficial del Estado, Madrid, España, 10 de octubre de 2011. Recuperado de http://bit.ly/2xwjRkJ

López Sánchez, J. (2012). El proceso concursal. Cizur Menor: Thomson Reuters.

López Santa María, J. (1998). Los contratos: parte general (2a ed., Vol. 1). Santiago: Editorial jurídica de Chile.

Miller, H. R. y Waisman, S. Y. (2005). Is chapter 11 bankrupcty?. Boston college law review, 47(1), 129-181. Recuperado de http://bit.ly/2TKBZ2Z

Núñez Ojeda, R., y Carrasco Delgado N. (2011). Derecho concursal procesal chileno: legislación, doctrina y jurisprudencia. Santiago: Thomson Reuter.

Núñez Ojeda, R. y Carrasco Delgado, N. (2014). Conceptos generales del análisis económico del Derecho concursal. En su, Presente y futuro del Derecho procesal concursal chileno. Una revisión desde el análisis económico del derecho (pp. 3-87). Santiago: Thomson Reuters.

Núñez Ojeda, R., Carrasco Delgado, N. y Ortiz Rojo, F. (2012). Visión crítica desde el análisis económico del derecho al sistema de verificación de créditos y realización de 
activos de la Ley de quiebras chilena. Ius et praxis, 18(1), 267-314. doi: 10.4067/s071800122012000100009

Palma Rogers, G. (1959). Legislación de quiebras. Santiago: Editorial Universitaria.

Pastor Prieto, S. (1993). ¡Ah de la justicia!, política judicial y economía. Madrid: Civitas.

Peinado Gracía, J. I. (2005). La distribución del riesgo de insolvencia. En M. Olivencia Ruiz, Estudios sobre la Ley concursal: libro homenaje a Manuel Olivencia (Vol. 1, pp. 427-466). Madrid: Marcial Pons.

Picker, R. C. (1992). Voluntary petitions and the creditors' Bargain. University of Cincinnati law review, 61, 519-541. Recuperado de http://bit.ly/2TIJ4kE

Pindyck, R. S. y Rubinfeld, D. L. (2001). Microeconomía. (E. Rabasco y L. Toharia, Trad.) (5a ed.). Madrid: Prentice Hall.

Posner, R. A. (1998). El análisis económico del derecho. (E. Suárez, Trad.). México: Fondo de Cultura Económica.

Posner, R. A. (1999). An economic approach to the law of evidence. Stanford law review, 51, 1477-1546. Recuperado de http://bit.ly/3aRvVM4

Provinciali, R. (1951). Manuale di diritto fallimentare (2a ed.). Milano: Giuffrè.

Provinciali, R. (1969). Manuale di diritto fallimentare (5a ed.). Milano: Giuffrè.

Puelma Accorsi, Á. (1983). Curso de derecho de quiebras (3a ed.). Santiago: Editorial jurídica de Chile.

Puga Vial, J. (1999). Derecho concursal: el juicio de quiebras (2a ed., Vol. 1). Santiago: Editorial jurídica de Chile.

Puga Vial, J. (2016). Mirada crítica de la Ley No 20.720. En E. Jequier Lehuedé (Ed.), Estudios de derecho concursal: la Ley No 20.720, a un año de su vigencia (pp. 47-67). Santiago: Thomson Reuters.

Pulgar Ezquerra, J. (2013). Refinanciación de deuda: un enfoque contractualista versus concursalista de la insolvencia. En F. Arias Varona (Dir.), Conservación de empresas en crisis: estudios jurídicos y económicos (pp. 3-29). Madrid: La Ley.

Ramírez López, J. (1959). La quiebra (Vol. 2). Barcelona: Editorial Bosch.

Rasmussen, R. K. (1992). Debtor choice: a menu approach to corporate Bankruptcy. Texas law review, 71, 51-121. Recuperado de http://bit.ly/2W8fK8K 
Romero Seguel, A. (2016). Aspectos procesales del Derecho concursal chileno. En E. Jequier Lehuedé (Ed.), Estudios de derecho concursal: la Ley $N^{\circ} 20.720$, a un año de su vigencia (pp. 149-178). Santiago: Thomson Reuters.

Satta, S. (1951). Instituciones del derecho de quiebra. (R. Fontanarrosa, Trad.). Buenos Aires: Ediciones Jurídicas Europa-América.

Schäfer, H.-B., y Ott, C. (2005). The economic analysis of civil law. Cheltenham: Edward Elgar.

Shavell, S. (2004). Foundations of economic analysis of law. Cambridge, MA: Belknap Press of Harvard University Press.

Tavano de Aredes, M. (2006). Coase: un teorema para el derecho. Su aplicación: a la responsabilidad civil, los derechos patrimoniales, al derecho de los contratos y al derecho de familia. En V. Kluger (Comp.), Análisis económico del derecho (pp. 59-86). Buenos Aires: Heliasta.

Teo, Hong Yin (2009). Bankruptcy law: is it really only about debt-collection?. Crosssections, 5, 115-121. doi: 10.22459/CS.V.2009

Tirado Martí, I. (2009). Reflexiones sobre el concepto de "interés concursal" ideas para la construcción de una teoría sobre la finalidad del concurso de acreedores. Anuario de derecho civil, 62(3), 1055-1108. Recuperado de http://bit.ly/2WcCepg

Tirado Martí, I. (2014). La reestructuración empresarial en el marco del derecho concursal español: un análisis crítico. En Á. Rojo Fernández, J. Quijano González y A. Campuzano Laguillo (Dir.), La liquidación de la masa activa. VI congreso español del derecho de la insolvencia (pp. 631-652). Cizur Menor: Thomson Reuters.

Warren, E. (1997). Making policy with imperfect information: the article 9 full priority debates. Cornell law review, 82(6), 1373-1395. Recuperado de http://bit.ly/2TL35Hj

\section{Para citar este artículo bajo Norma APA 6a ed.}

Carrasco Delgado, N. I. (2020). El concurso desde una pers-

pectiva procesal. Revista de Derecho (Coquimbo. En línea), 27,

e4040, https://doi.org/10.22199/issn.0718-9753-2020-0001

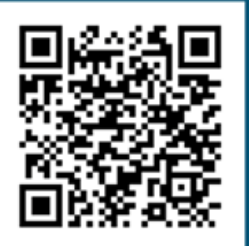

DOI

Este es un artículo de acceso abierto, bajo licencia Creative Commons BY 4.0. 